\title{
ERRORS AND FRAUD IN ACCOUNTING. THE ROLE OF EXTERNAL AUDIT IN FIGHTING CORRUPTION
}

\author{
Luminița IONESCU ${ }^{1}$, \\ ${ }^{1}$ Spiru Haret University, 13 Ion Ghica Street, Bucharest, 030045, Romania, \\ Tel.: +40214551000, Fax: +40213143900, \\ Email: se_lionescu@spiruharet.ro
}

\begin{abstract}
Accounting errors and fraud are common in most businesses, but there is a difference between fraud and misinterpretation of communication or accounting regulations. The role of management in preventing fraud becomes important in the last decades and the importance of auditing in curbing corruption is increasingly revealed. There is a strong connection between fraud and corruption, accelerated by electronic systems and modern platforms.

The most recent developments tend to confirm that external auditing is curbing corruption, due to international accounting and auditing standards at national and regional levels. Thus, a better implementation of accounting standards and high quality of external control could prevent errors and fraud in accounting, and reduce corruption, as well.

The aim of this paper is to present some particular aspects of errors and fraud in accounting, and how external audit could ensure accuracy and accountability in financial reporting.
\end{abstract}

Keywords: corruption; government; audit; accounting.

JEL Classification: $\mathrm{D}_{73}, \mathrm{H}_{70}, \mathrm{H}_{83}, \mathrm{M}_{48}$

\section{Introduction}

This paper covers some particular aspects of errors and fraud in accounting, characteristics of fraud and explains how external audit could prevent the misstatements in the financial statements. According to International Standards of Auditing (ISA) the management is responsible for implementing accounting policies and for maintaining internal control, the auditor's responsibility is to express their opinion on the fairness of financial statements. It is common knowledge that the phenomenon of corruption cannot be eradicated altogether, for it exists in all 

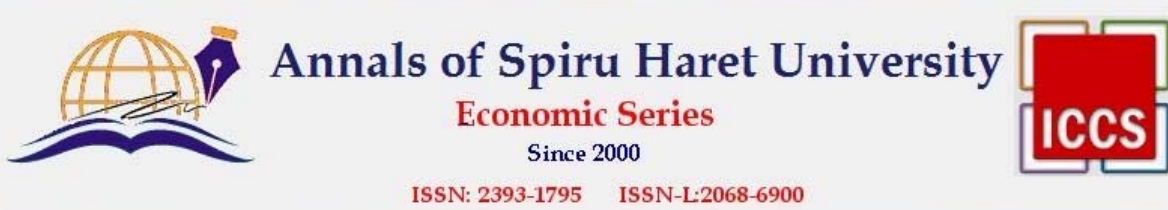

\section{Issue 4/2017}

countries, but corruption must have a controllable level and could be prevented by implementing internal control, internal audit and external audit [Ionescu, 2012a].

Corruption is related to fraud, financial crime, currency counterfeiting, money laundering, intellectual property crime, payment card fraud, computer virus attacks, etc. [Zaman \& Ionescu, 2014]. The damaging effects of fraud and corruption could be identified in financial reporting with overpayment or recording non-delivery of goods and services for third-party transactions [Evans, 2008]. Recently, auditors are playing a central role in fighting against corruption and detecting errors or fraud with significant impact on the financial statements or other management reports [Bunget \& Dumitrescu, 2009].

The development of fraud and corruption in Romania is facilitated by the internal and external environment marked by a high degree of uncertainty and vulnerability, connected to the international context of 2016-2017 emphasized by BREXIT at European level [Gurgu \& Zorzoliu, 2016]. The economic crisis became a big challenge for the European Union and there are deep differences among member states on their understanding of economic and financial behaviour [Lorca-Sussino, 2016]. There is big difference between error and fraud. According to ISA 240 The Auditor's Responsibilities Relating to Fraud in an Audit of Financial Statements, fraud is "an intentional act by one or more individuals among management, those charged with governance, employees or third parties, involving the use of deception to obtain an unjust or illegal advantage". Fraud and corruption have grown in the last decades due to the conflict of interest, poor management and bureaucracy costs. We can observe in the figure below the relation between fraud, poor management and corruption.

According to ISA 240 The Auditor's Responsibilities Relating to Fraud in an Audit of Financial Statements, the auditor may identify the occurrence of fraud and corruption, but the auditor does not make legal connection between fraud and corruption, and the responsibility for the prevention and detection of fraud is the role of the company's management. Independence of the auditor is important in order to be objective during performing the auditing duties. 


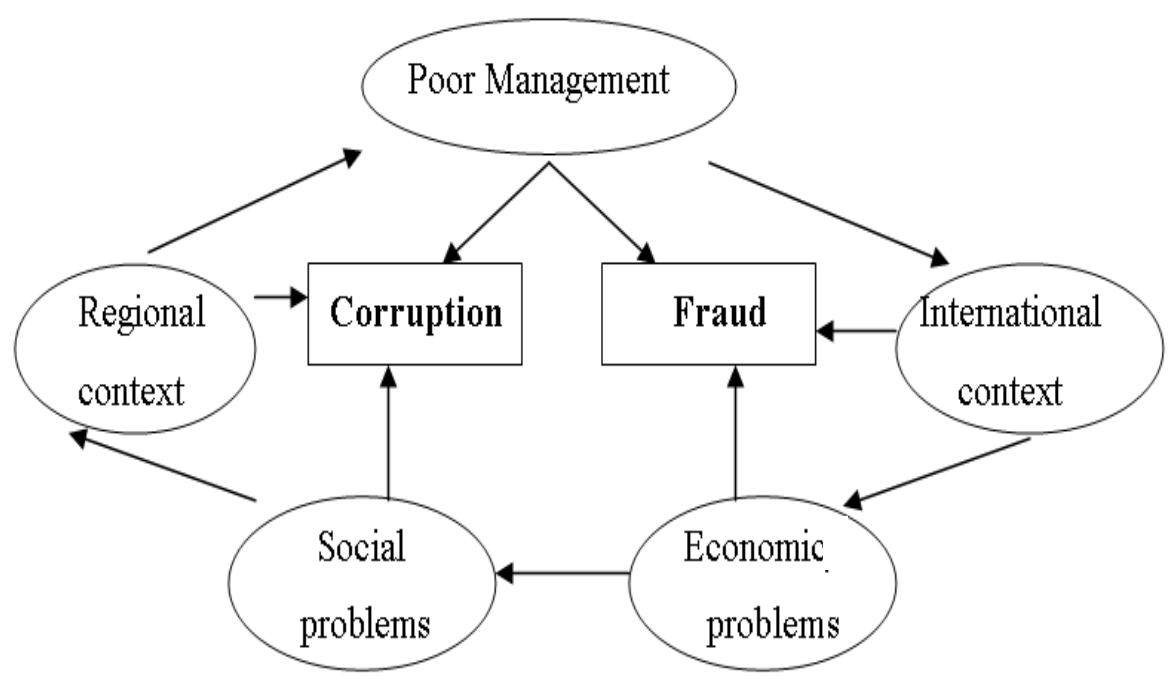

Figure no. 1. The relation between fraud, poor management and corruption Source: Authors' own work

The perception of corruption and fraud in Romania

Accounting may facilitate bureaucracy and corruption, especially since regulation changes and the implementation of European directives in the national accounting system, including the requirements of financial-banking institutions or international bodies, are produced at a relatively high frequency [Ionescu, 2012b]. The reform of the Romanian accounting system has created prerequisites for the development of bureaucracy and corruption for at least two reasons:

a) inaccuracies, incompatibilities and confusion, both in respect of new and old accounting rules;

b) lack of clear, comprehensive and easy to use instructions and methodologies.

In this context, numerous accounting errors have been discovered, either due to erroneous records or due to software deficiencies. However, fraud and corruption are permanent problematic factors for doing business in Romania, as we can see in Table no. 1: 
Issue 4/2017

Table no. 1. The evolution of five problematic factors for doing business in Romania

\begin{tabular}{|l|c|c|c|c|c|c|c|}
\hline \multirow{2}{*}{ Indicators Romania } & \multicolumn{7}{|c|}{ Years } \\
\cline { 2 - 8 } & & & & & & & \\
\cline { 2 - 8 } & 2009 & 2010 & 2011 & 2012 & 2013 & 2014 & 2015 \\
\hline - bureaucracy & 12.2 & 13.0 & 12.8 & 10.2 & 9.9 & 14.7 & 15.9 \\
\hline- corruption & 6.9 & 9.7 & 17.4 & 13.4 & 11.0 & 8.7 & 10.1 \\
\hline- tax rates & 11.6 & 15.5 & 13.9 & 17.8 & 15.6 & 15.8 & 14.7 \\
\hline - access to financing & 15.9 & 10.8 & 12.1 & 10.5 & 16.6 & 14.0 & 16.6 \\
\hline - tax regulations & 11.2 & 8.7 & 7.6 & 11.8 & 9.9 & 7.4 & 7.4 \\
\hline
\end{tabular}

Source: http://www3.weforum.org/docs, Global Competitiveness Reports

Analyzing the indicators from table no. 1, we observe that bureaucracy, corruption, tax rates and access to financing record a high score as problematic factors for doing business in Romania. The evolution of perception of corruption is presented in the figure below:

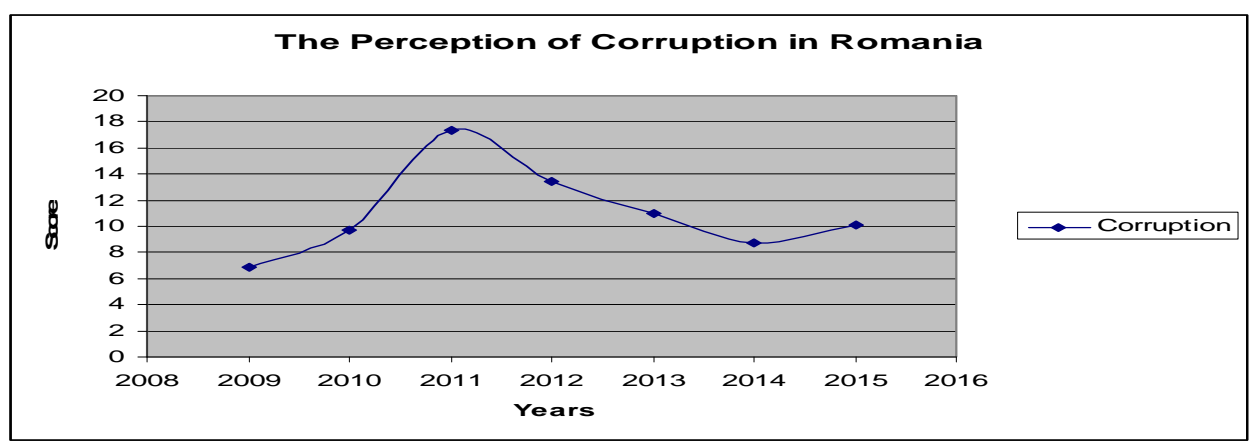

Figure no. 2. The perception of corruption period 2009-2015

Source: http://www3.weforum.org/docs, Global Competitiveness Reports 


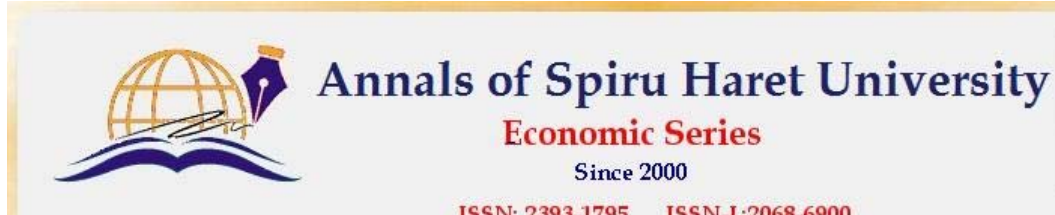

ISSN: 2393-1795 ISSN-I*2068-6900

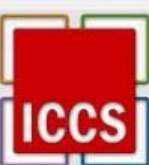

Issue 4/2017

Failure by auditors to detect such errors, mistakes and fraudulent activities could undermine the accuracy and transparency of the financial statements, leading to misrepresentation of expenses, costs, assets and profit or loss. According to Transparency International (2017), the recent economic crisis reveals accounting scandals with errors or fraud in the financial reports.

\section{Prevention of errors and fraud in accounting}

Fighting against corruption and fraud became a priority for governments, but also for professional organizations, as well. In Romania, The Body of Experts and Licensed Accountants of Romania (CECCAR) is the leader of the accounting profession, adopting accounting norms and encouraging all the members to fight against corruption and fraud. The Superior Council of CECCAR has decided to adopt the International Code of Ethics for Professional Accountants issued by IFAC as its own National Code of Ethics for Professional Accountants, for periods beginning on or after January $1^{\text {st }}, 2011$.

One of the fundamental principles of the National Code of Ethics is professional competence and due care in order to maintain professional knowledge and skill at the required level to avoid errors and mistakes. Another important ethical principle is referring to professional behaviour, in order to comply with relevant laws and regulations and avoid any action that discredits the profession. According to National Code of Ethics for Professional Accountants, a professional accountant discovering a significant error when evaluating the accounting reports from the past must correct the error, in order to avoid the misleading information in the financial statements.

Errors, fraud and corruption could be prevented by implementing principles from the Code of Ethics and auditing procedures. In this research, we developed a survey undertaken by over 100 accountants, expert accountants and managers from public and private companies in Bucharest and the suburbs. The questions were referring to the existence of errors and fraud in the accounting system and the role of audit in minimizing corruption. About 15\% of the participants were expert accountants and $90 \%$ were accountants, all of them had university/college degrees. Thus, in the first question, we asked the respondents if, in their opinion, financial reporting included many errors. Here are the results: $90 \%$ of the respondents said NO (there are no mistakes), 3\% of the respondents said YES (sometimes there are some mistakes), while the remaining said they did not know. We present the results in the figure below: 
Issue 4/2017

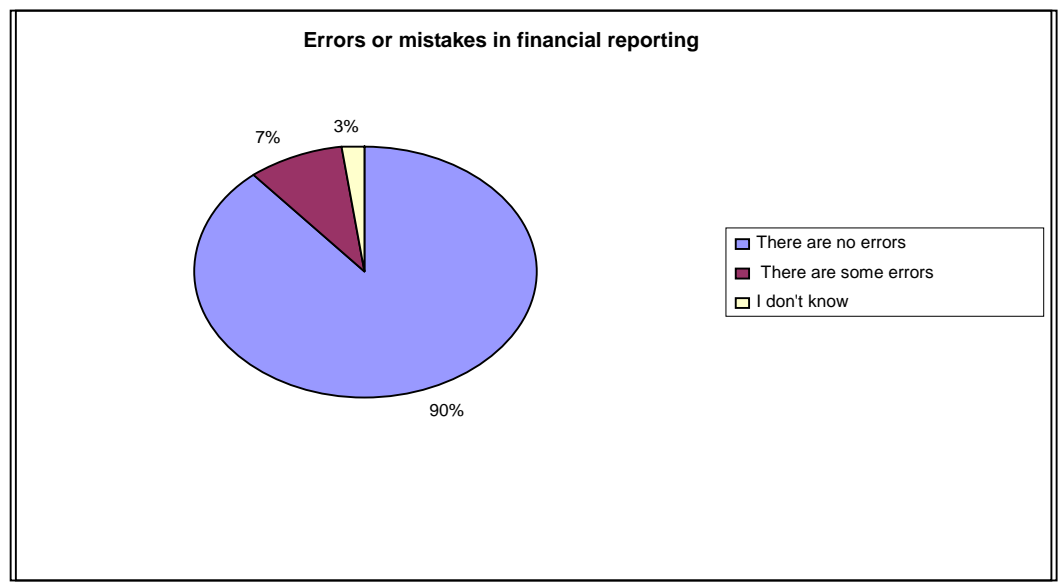

Figure no. 3. Errors in financial reporting Source: Authors' own work

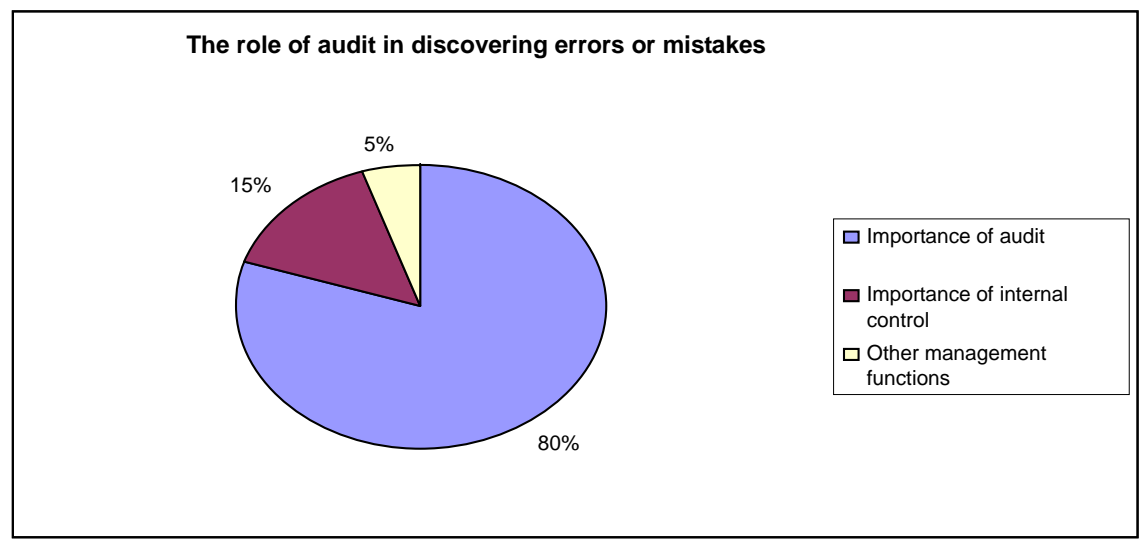

Figure no. 4. The role of audit in discovering errors or mistakes Source: Authors' own work

Then, in the second question, the respondents were asked whether they believed in the role of audit in discovering errors or mistakes. Therefore, $80 \%$ of the respondents said YES, external audit can reveal the errors and fraud from financial reporting, while $15 \%$ of the respondents said that internal control is more 


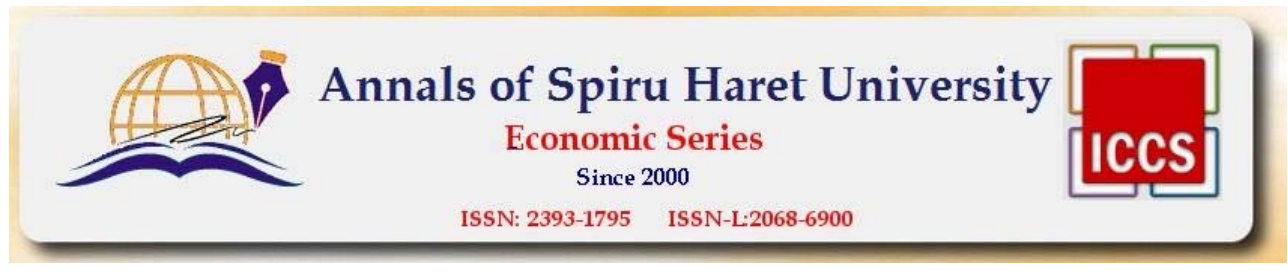

Issue $4 / 2017$

important, and 5\% said there are some other methods to prevent or discover mistakes. The results are presented in the figure above.

In fact, external auditors have limited investigative powers which restrict their ability to further investigate corruption cases or fraud [Evans, 2008]. It is the function of the management or financial controller to implement control techniques and prevent the errors or fraud in primary documents and financial statements. According to ISA 240 The Auditor's Responsibilities Relating to Fraud in an Audit of Financial Statements, management of the company is in a unique position to facilitate fraud because of management's ability to manipulate accounting records and prepare fraudulent financial statements by overriding controls that otherwise appear to be operating effectively.

\section{Conclusion}

Errors and mistakes in accounting are common and, most of the time, they are discovered by implementing internal control techniques or auditing procedures. Errors are due to misinterpretation of the accounting regulations or principles and mistakes are, most of the time, human errors. Fraud in accounting is more complex and involves the managers or employees who have access to documents or transactions during the year. The role of external audit in discovering errors and fraud is important, because fraud is connected to money laundering and corruption. Fraud and bureaucracy are causes of corruption and they could be minimized by implementing the International Accounting Standards and the International Standards of Auditing.

\section{References}

1. Bunget, O.C. \& Dumitrescu, A.C., "Detecting and Reporting the Frauds and Errors by the Auditor," Annales Universitatis Apulensis Series Oeconomica 11(1), (2009): 117-125.

2. Evans, A., The Role of Supreme Audit Institutions in Combating Corruption, Transparency International, U4 Expert Answers, www.u4.no/.../the-role-of-supremeaudit-institutions,

3. Gurgu, E. \& Zorzoliu, R., "Romania's Main Role in the Current Global Economic Context," Annals of Spiru Haret University Economic Series, Volume 16(3), (2016): 20-36.

4. Ionescu, L., Principles and Hypothesis on Bureaucracy and Corruption Phenomena, Postdoctoral Research, Romanian Academy (Bucharest, 2012).

5. Lorca-Sussino, M., The European Union Decoded: Challenges Beneath the Surface (Taylor \& Francis Ltd, 2016). 


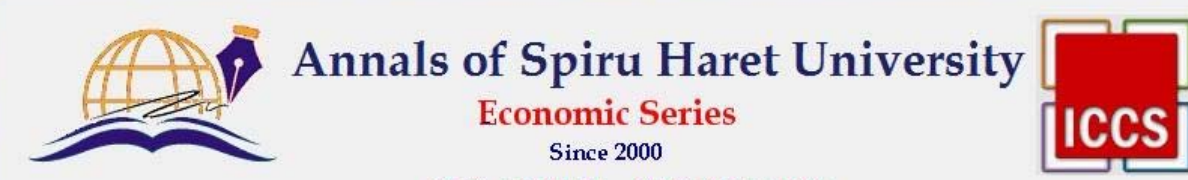

ISSN: 2393-1795 ISSN-L:2068-6900

Issue 4/2017

6. Zaman, G. \& Ionescu, L., "The Impact of International Economic Crises on Corruption in Romania,” ECOCYB, Volume no. 12/2014, ASE, Bucharest (2014): 65-81.

7. www.weforum.org - Global Competitiveness Report 2015-2016.

8. https://www.transparency.org/whatwedo/ - Transparency International, The Role of External Auditing in Fraud and Corruption, 2017.

9. http://ceccar.org/en - National Code of Ethics for Professional Accountants. 